\title{
SPECIATED HYDROCARBON ANALYSIS IN EXHAUST EMISSIONS OF FLEX-FUEL VEHICLES
}

\author{
Graciela Arbilla ${ }^{1}$, Cleyton Martins da Silva ${ }^{1}$, Bruno Siciliano ${ }^{1}$, Pedro Vicentini ${ }^{2}$, Luciana \\ Loureiro $^{2}$, José Claudino Almeida ${ }^{3}$ e Luiz Carlos Daemme ${ }^{4}$ \\ ${ }^{1 .}$ Universidade Federal do Rio de Janeiro \\ 2. PETROBRAS \\ ${ }^{3 .}$ FIRJAN - SENAI \\ ${ }^{4 .}$ LACTEC
}

E-mails: gracielaiq@gmail.com, martins.cleyton@gmail.com, sicilianoiq@gmail.com, pcvicentini@petrobras.com.br, lloureiro@petrobras.com.br, joseclaudino.SENAI@petrobras.com.br, luiz.carlos@lactec.org.br

\begin{abstract}
In urban environments, vehicle emissions are the main source of hydrocarbons (HC) which contribute to formation of tropospheric ozone. Since individual HC exhibit a wide range of ozone formation reactivity, speciated analyzes are necessary to assess the overall impact of vehicle exhaust emissions. Flex-fuel represents more than $90 \%$ of the light duty vehicle sales in Brazil. In this project, sampling and analytical methods were implemented and optimized for determination of speciated $\mathrm{HC}\left(\mathrm{C}_{4}-\mathrm{C}_{12}\right)$. Three flex-fuel vehicles (PROCONVE L4, L5 and L6) were tested, with both gasoline (E22) and ethanol (E100). Vehicle exhaust samples were obtained during emissions testing with FTP75 drive cycle (according to ABNT/NBR 6601) for each of the three phases: cold start, stabilized and hot start. The exhaust was collected in Tedlar bags and transferred to electropolished stainless steel canisters. HC were analyzed using thermal desorption and gas chromatography with a mass spectrometry detector. The analytical procedure was based on Method TO-15 (US EPA). Quantification was performed using a standard reference mixture that covered the entire concentration range of the samples. Using gasoline, E22, experimental emission values for phase 1 were 0.037 , 0.017 and $0.019 \mathrm{~g} \mathrm{HC}\left(\mathrm{C}_{4}-\mathrm{C}_{12}\right) \mathrm{km}^{-1}$ for PROCONVE L4, L5 and L6 vehicles, respectively. Average MIR values (specific reactivity) for exhaust phase 1 were 3.04, 3.03 and 2.27, respectively, for PROCONVE L4, L5 and L6 vehicles. Weighted Maximum Incremental Reactivity (MIR) and Ozone Formation Potential (OFP) values, for $\mathrm{C}_{4}-\mathrm{C}_{12}$ fraction, were approximately in the intervals 2.00-2.76 and 0.013-0.099, respectively. Aromatic organic compounds in the exhaust of ethanol tests were $<1 \mathrm{ppmC}$ for all phases and vehicles. Results suggest that these compounds are not due to the combustion of ethanol and their contribution for total $\mathrm{HC}\left(\mathrm{C}_{4}-\mathrm{C}_{12}\right)$ reactivity was considered negligible. A new method will be implemented in future tests to determine the low $\mathrm{HC}$ fraction $\left(\mathrm{C}_{2}\right.$ and $\left.\mathrm{C}_{3}\right)$ by chromatography. Speciated HC emission data may be useful for technical discussions about the ozone formation potential using Brazilian fuels.
\end{abstract}

\section{INTRODUCTION}


Tropospheric ozone is a criteria pollutant formed in the atmosphere by photochemical reactions in the presence of sunlight and precursors pollutants, mainly oxides of nitrogen $\left(\mathrm{NO}_{\mathrm{x}}=\mathrm{NO}+\mathrm{NO}_{2}\right)$ and volatile organic compounds (VOC) [1]. Several studies have shown that ozone concentrations correlate with various other toxic photochemical oxidants, arising from similar sources, including the peroxyacyl nitrates, nitric acid and hydrogen peroxide. The photochemical processes related to tropospheric ozone formation have been extensively discussed in the literature [2]. In the troposphere, ozone is formed when $\mathrm{NO}_{2}$ photodissociate into $\mathrm{NO}$ and oxygen atom $\left(\mathrm{O}\left({ }^{3} \mathrm{P}\right)\right)$, as shown in reaction 1 . The $\mathrm{O}\left({ }^{3} \mathrm{P}\right)$ atom combines with $\mathrm{O}_{2}$ to form $\mathrm{O}_{3}$ (reaction 2). The reaction of $\mathrm{O}\left({ }^{3} \mathrm{P}\right)$ with $\mathrm{O}_{2}$ is the only known anthropogenic source of tropospheric ozone. In the absence of VOC, ozone reacts rapidly with NO to regenerate $\mathrm{NO}_{2}$ (reaction 3) and its concentration depends on the $\mathrm{NO}_{2} / \mathrm{NO}$ ratio and the rate of photolysis. However, in the presence of VOC, free radicals are generated in the process of VOC oxidation by hydroxyl radical $(\cdot \mathrm{OH})$ and others photochemical oxidants, such as $\mathrm{O}_{3}$ and $\mathrm{NO}_{3}$, leading to the conversion of $\mathrm{NO}$ to $\mathrm{NO}_{2}$ and a variety of potential reaction paths through the formation of another free radical (reaction 4). Radicals formed in reaction 4 may also react with $\mathrm{NO}_{2}$ removing it from the system in a chain termination reaction (reaction 5). Thus, $\mathrm{NO}_{\mathrm{x}}$ acts both to promote $\mathrm{O}_{3}$ formation (reactions 1,2 and 4) and to inhibit $\mathrm{O}_{3}$ formation (reaction 3 and 5). Net photochemical formation of $\mathrm{O}_{3}$ versus net photochemical loss of $\mathrm{O}_{3}$ in the troposphere, therefore, depends primarily on the $\mathrm{VOC} / \mathrm{NO}$ ratio (more than absolute concentrations of precursors) and also on the reactivity of the VOC mixture [3]. At high $\mathrm{VOC} / \mathrm{NO}_{\mathrm{x}}$ ratios the system becomes $\mathrm{NO}_{\mathrm{x}}$-controlled. At low $\mathrm{VOC} / \mathrm{NO}_{\mathrm{x}}$ ratios, the system is VOC-controlled, and ozone formation depends both on VOC concentration and speciation.

$$
\begin{array}{lc}
\mathrm{NO}_{2} \rightarrow \mathrm{NO}+\mathrm{O} & \text { (reaction 1) } \\
\mathrm{O}+\mathrm{O}_{2} \rightarrow \mathrm{O}_{3} & \text { (reaction 2) } \\
\mathrm{NO}+\mathrm{O}_{3} \rightarrow \mathrm{NO}_{2}+\mathrm{O}_{2} & \text { (reaction 3) } \\
\cdot \mathrm{RO}_{2}+\mathrm{NO} \rightarrow \mathrm{NO}_{2}+\cdot \mathrm{RO} & \text { (reaction 4) } \\
\cdot \mathrm{RO}+\mathrm{NO}_{2} \rightarrow \mathrm{RONO}_{2} & \text { (reaction 5), } \\
\text { where } \mathrm{R} \text { stand for } \mathrm{H} \text { or a hydrocarbon fragment. }
\end{array}
$$

Strategies to control tropospheric ozone and other photochemical oxidants focus on its precursor gas emissions. In urban areas, light duty vehicles are the main VOC emission source. To properly address the related air quality and health problems associated to ozone formation, reliable source data of VOC are important to developing effective control technologies. Speciated VOC emission sources are also useful for air quality modelling [4].

Today flex-fuel represents more than $90 \%$ of the light duty vehicle sales in Brazil, but there were only two published studies regarding tail pipe $\mathrm{HC}$ speciation of national vehicles and fuels. These tests were performed by Melo et al [5] using a L3 vehicle and by Graner et al [6] with a L5 model both running with gasoline (E22) and hydrous ethanol (E100). The samples were analyzed abroad since there was no laboratory able to do this in Brazil. The HC specific reativity of gases found by Melo et al [5] was very different than the one determined by Graner et al. [6] and it was noticed that there was no direct correlation between the HC species in exhaust gas and fuel composition. Both studies presented unexpected content of aromatics hydrocarbons in the exhaust (22\% to 55\%) when using hydrous ethanol.

The main goal of this study is to describe the implementation of a method in a Brazilian laboratory to determine the hydrocarbons ( $\mathrm{HC}$, non-oxygenated volatile organic compounds), in the interval $\mathrm{C}_{4}-\mathrm{C}_{12}$, emitted by flex-fuel vehicles using gasoline and hydrous ethanol, based 
on the ABNT NBR 6601 Brazilian Standards and international procedures to determine the organic compounds, as well as to calculate the ozone forming potential of the gas mixture due to HC. Weighted Maximum Incremental Reactivity (MIR) and Ozone Formation Potential (OFP) values were also calculated for the $\mathrm{C}_{4}-\mathrm{C}_{12} \mathrm{HC}$ fraction exhaust using gasoline. The contribution of oxygenated species, such as ethanol and carbonyl compounds (CC) should also be considered in the calculation of the Non-Methane Organic Gases (NMOG) mass and in the OFP calculation. However, the determination of oxygenated compounds will not be discussed in this work, since experimental methods for these compounds are well stablished and discussed in previous works [5]. Since the method used in this study is not adequate to determine $\mathrm{HC}\left(\mathrm{C}_{2}-\mathrm{C}_{3}\right)$, relative concentrations obtained by Fourier Transform Infrared Spectroscopy (FTIR) were used in gasoline tests to estimate the MIR and OFP values for total non-methane hydrocarbons (NMHC).

\section{MATERIAL AND METHODS}

\subsection{Vehicles, fuels and driving conditions}

Previous studies have shown that the concentration and type of volatile organic compounds depend on the vehicle model, technology level, mileage, engine condition, fuel type, and operational factors such as speed, acceleration, gear selection and road gradient [7]; [8]. Among all the technologies to measure emissions from vehicles, the chassis dynamometer is commonly employed to acquire an uniform source profile for vehicle evaluation and regulatory purpose [7]; [9]; [10]. The chassis dynamometer can simulate various engine operation conditions using different driving cycles, which are fixed schedules of vehicle operation which allow an emission test to be conducted under reproducible conditions. More than 200 driving cycles have been described [7]. The Federal Test Procedure (FTP75) is mandatory for new light duty vehicles in the United States [11], while the New European Driving Cycle (NEDC), which is a version of the former MVEG-A cycle (also known as the ECE/EUDEC) is used in European Union [12]. In Brazil, the driving conditions are similar to the US test and were established by the Brazilian Association of Technical Standards (ABNT), referred as ABNT NBR 6601 [9].

Three flex-fuel light duty vehicles were used: PROCONVE L4 (PFI, 2.0L, model 2008), PROCONVE L5 (PFI, 1.0L, model 2011) and PROCONVE L6 (GDI, 1.6L, model 2016). Fuels used in this study were reference gasoline E22 (with $22 \% \mathrm{v} / \mathrm{v}$ anhydrous ethanol) and commercial hydrous ethanol with up to $4.9 \%$ v/v of water (E100). For each vehicle, duplicate tests were performed with gasoline and ethanol. The driving conditions met the procedure published by the Brazilian Association of Technical Standards (ABNT), referred as ABNT NBR 6601 [9]. The whole emissions test consists of the following segments:

1. Phase 1: Cold start transient phase (ambient temperature $20-30^{\circ} \mathrm{C}$ ), 0-505 s,

2. Phase 2: Stabilized phase, 506-1372 s,

3. Hot soak (a break of 10 minutes),

4. Phase 3: Hot start transient phase, 0-505 s.

Each vehicle was set on the chassis dynamometer with constant volume sampler (CVS 7200 series, HORIBA). Emissions from each phase were diluted and collected in separated Tedlar bags. The exhaust of each phase and the dilution ambient air for each phase were analyzed by dedicated analyzers $\left(\mathrm{CO}, \mathrm{CH}_{4}, \mathrm{THC}, \mathrm{NO}_{\mathrm{x}}, \mathrm{CO}_{2}\right)$. These tests were performed at facilities of Petrobras Research Center (CENPES). 
In Figure 1, the chassis dynamometer, the constant volume sampler and the Tedlar bags are shown.

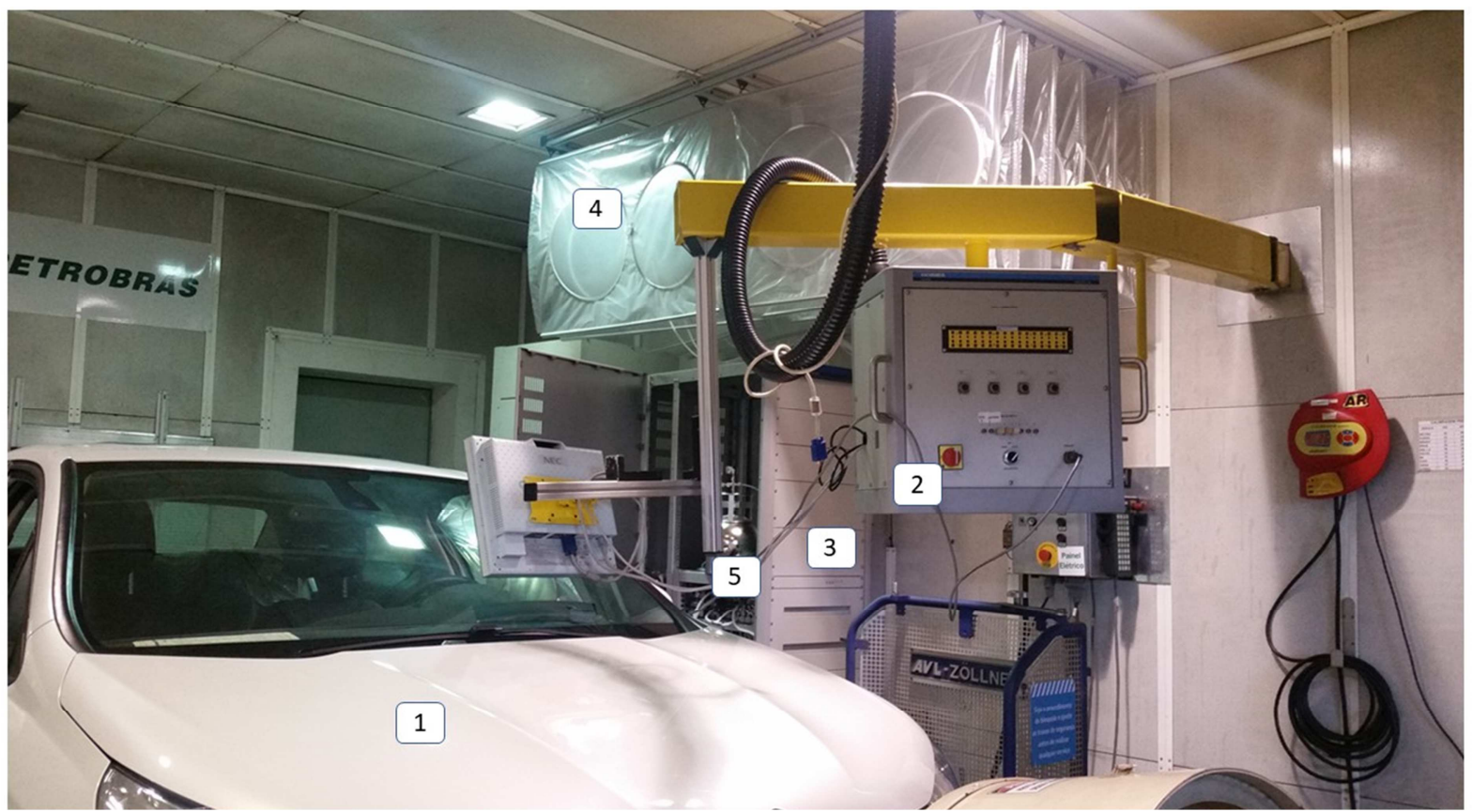

Figure 1. Laboratory of Vehicular Emissions in Petrobras Research Center. Vehicle and chassis dynamometer (1 and 2), constant volume sampler, CVS HORIBA (3), Tedlar bags (4) and canisters (5) used in the tests.

A strict fuel change procedure and analysis protocol was applied to avoid contamination. The fuel change was performed as follows: the fuel was drained, and the tank was flushed with 5 $\mathrm{L}$ of the new fuel. Then, this fuel was drained again and after filling the tank with $30 \mathrm{~L}$, the vehicle was run for $30 \mathrm{~km}$, before the pre-conditioning test, which was performed following the ABNT NBR 6601.

\subsection{Hydrocarbons analysis $\left(\mathrm{C}_{4}-\mathrm{C}_{12}\right)$}

The diluted exhaust and the dilution ambient air of each phase were collected in $6.0 \mathrm{~L}$ stainless steel canisters (Restek Silonite ${ }^{\circledR}$ ) with TOV $-2^{\mathrm{TM}}$ valves, by active sampling using a pumping device (Figure 2). The sampling line was previously purged with the sample contained in the Tedlar bags to avoid contamination. Before sampling, the canisters were cleaned using a cleaning system (RM Environmental Systems Inc., model 960, CA, USA). Briefly, all canisters were evacuated to $500 \mathrm{mTorr}$ at $120^{\circ} \mathrm{C}$ and maintained in vacuum for 60 min. Then, the canisters were filled with humidified (50\% relative humidity) helium $(\mathrm{He})$ to 30 psig. This cycle was completed three more times for a total of four cycles; then, four additional cycles were completed with dry He. Blank samples were generated by pressurizing the clean canisters with He. The canisters were considered clean if less than $0.2 \mathrm{ng}$ of each target compound was detected. Then, the canisters were evacuated below 5 mTorr prior to use. All canisters were labeled and were always used for the same type of sample (exhaust phase 1 , exhaust phase 2, etc.). 


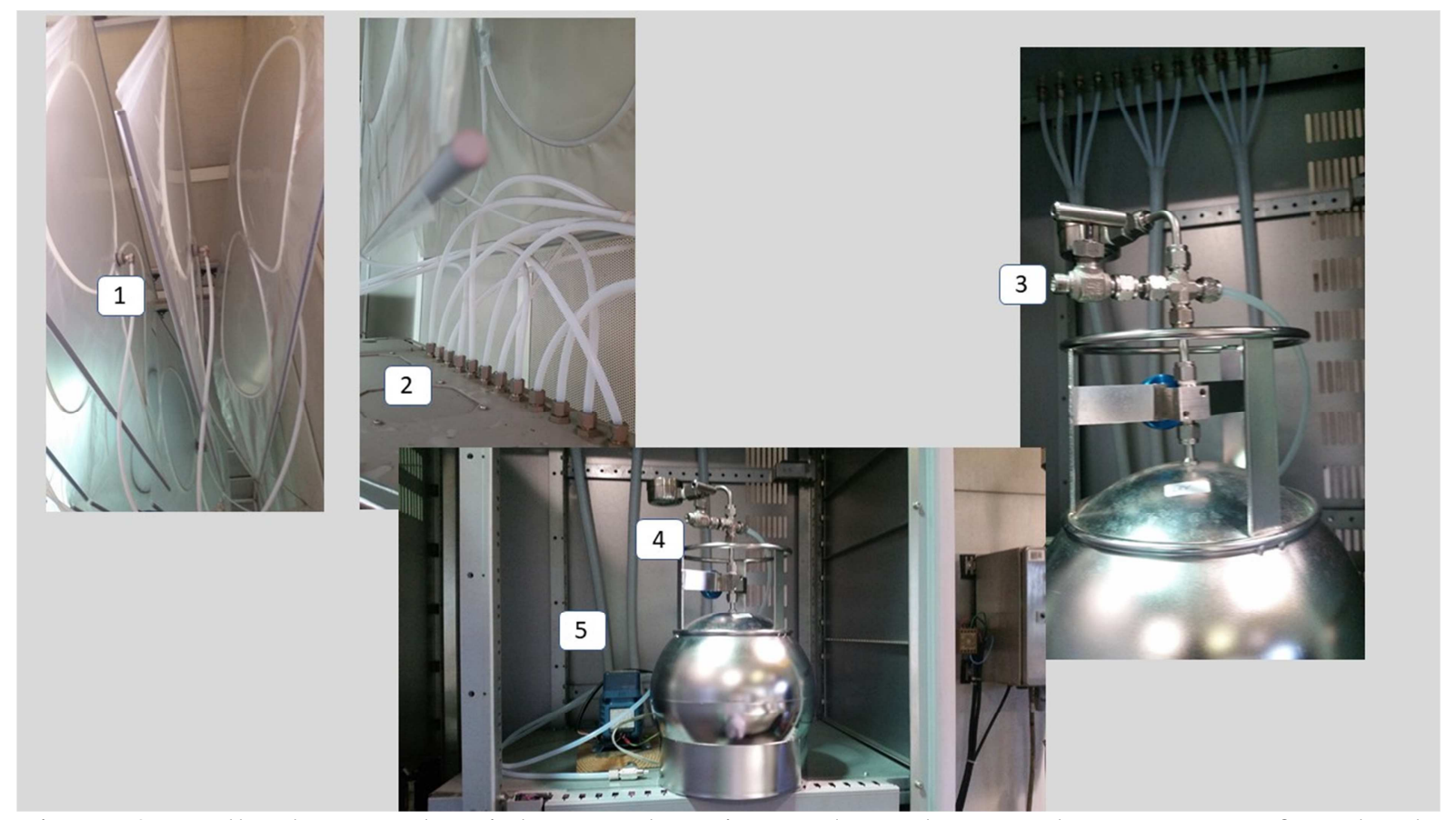

Figure 2. Tedlar bags and stainless-steel canister where the samples were transferred. The sample in the bag was transferred using a Teflon tube (connections 1 and 2) and a three-way valve (3). The system was previously purged using valve (4) and a small electrically powered pump (5).

After sampling at Laboratory of Vehicular Emissions, the canisters were taken back to the Laboratory of Atmospheric Chemistry and Pollution/UFRJ and were kept at temperatures in the interval $20-22{ }^{\circ} \mathrm{C}$. The samples were analyzed within 48 hours on a gas chromatograph with a thermal desorption and mass spectrometer detection (GC/MS/TD) system (Agilent, model GC 7890A, MS 5975C, CA, USA and Markes CIA Advanced, OH, USA) according to the TO-15 Method [13], which has been previously optimized in the UFRJ laboratory for ambient samples [14]. In this study some modifications were required to attend high pollutant concentrations and humidity of vehicular exhaust.

For tests with ethanol, the cold trap system was cleaned before analyzing the samples and a blank test was run to guarantee that the chromatographic system was not contaminated by previous gasoline tests. Furthermore, exhaust samples were analyzed within 24 hours to avoid contamination.

Samples were directed from the canister (flow rate of $20 \mathrm{~mL} \mathrm{~min}^{-1}$ ) through a Nafion dryer trap to reduce the water vapor and ethanol content below any threshold affecting the proper operation of the analytical system. It was then directed through a cold trap containing carbon molecular sieves (Markes U-T3ATX-2S) at $10{ }^{\circ} \mathrm{C}$ to retain the target compounds. The compounds were then thermally desorbed $\left(300{ }^{\circ} \mathrm{C}\right)$ and transferred to a DB-624 gas chromatographic column for separation $(60 \mathrm{~m} \times 0.32 \mathrm{~mm} \times 1.80 \mu \mathrm{m})$. He $5.0(99.999 \%$, ultra high purity grade) was used as the carrier gas at a constant flow of $3.5 \mathrm{~mL} \mathrm{~min}^{-1}$. The oven temperature program was set as follows: $25^{\circ} \mathrm{C}$ for $5 \mathrm{~min}, 25^{\circ} \mathrm{C}$ to $50{ }^{\circ} \mathrm{C}$ at $0.8{ }^{\circ} \mathrm{C} \mathrm{min}{ }^{-1}$, $50{ }^{\circ} \mathrm{C}$ to $250{ }^{\circ} \mathrm{C}$ at $5{ }^{\circ} \mathrm{C} \mathrm{min}^{-1}$ and $250{ }^{\circ} \mathrm{C}$ for $3 \mathrm{~min}$. The injector temperature was $190{ }^{\circ} \mathrm{C}$. This analytical method is recommended for $\mathrm{HC}$ compounds in the interval from $\mathrm{C}_{4}$ to $\mathrm{C}_{12}$. For the determination of propane and propene the initial temperature column should be approximately $-40^{\circ} \mathrm{C}$, while the determination of ethane and ethane should be performed with 
another column (such as GS-Q or Plot Q) and initial temperatures of approximately $-60{ }^{\circ} \mathrm{C}$ [15]; [16].

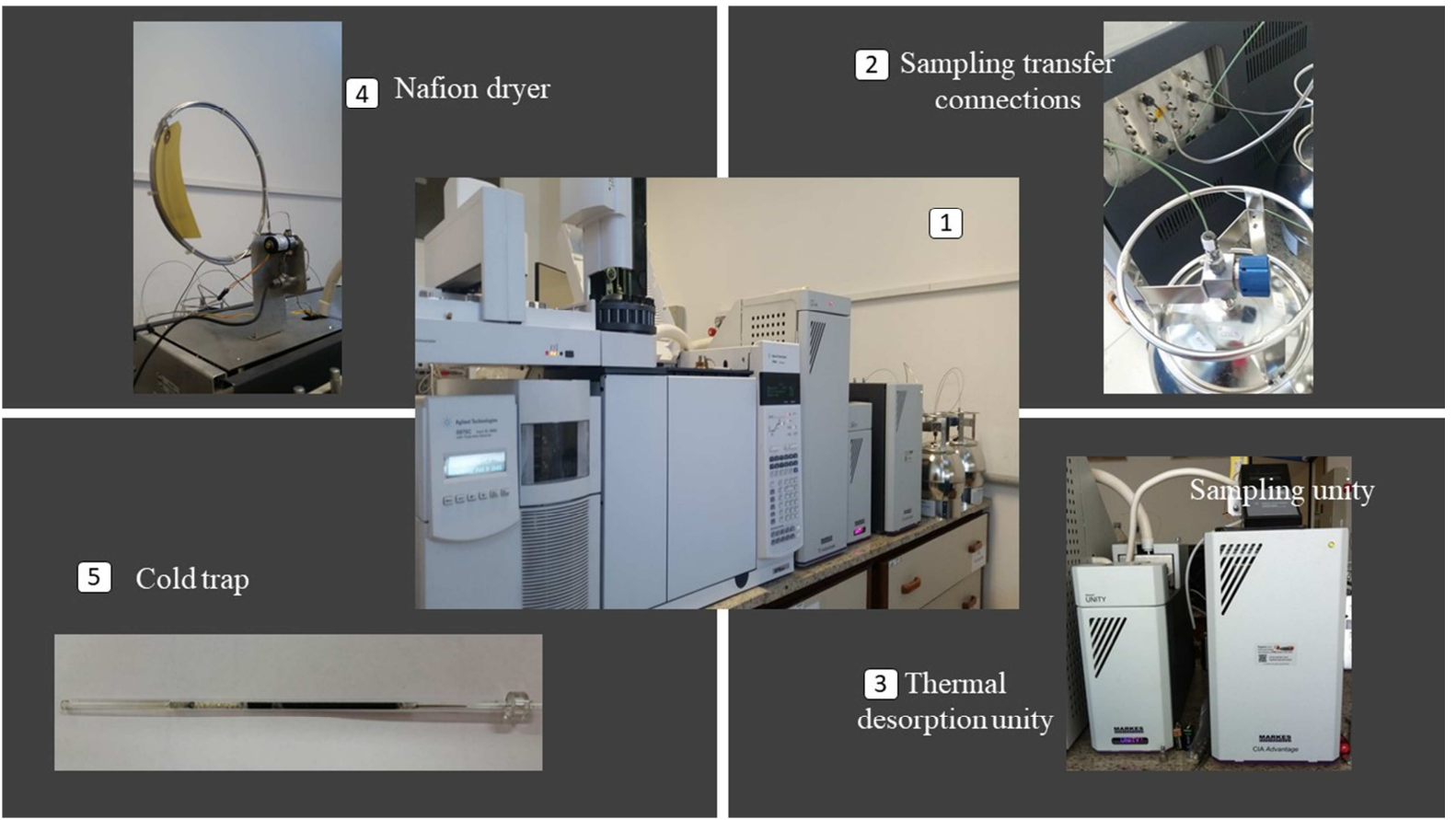

Figure 3. (1) Chromatographic system (GC/MS/TD), (2) Transfer connections, (3) Sampling and desorption Unities, (4) Nafion dryer and (5) cold trap used to transfer and analyze the samples (Laboratory of Atmospheric Chemistry and Pollution/UFRJ).

Each compound was identified by matching the retention time and mass spectrum of the unknown compound with those of a standard reference mixture (57 compounds, Restek, 100 ppb, PO\#127804, PA, USA). Both scan mode and selective ion monitoring (SIM) of the most abundant ions were used to ensure the correct identification of all compounds. Quantification was performed using selective ion monitoring (SIM) of the most abundant ions, based on an external analytical curve using the standard reference mixture that covered the entire concentration range of the samples. The calculated determination coefficients for all compounds were greater than 0.99 . The analytical curve was constructed in triplicate, using five concentration levels and points were verified daily for quality control. The limits of detection (LOD) and quantification (LOQ), which were calculated from the noise standard deviation, were $0.2 \mathrm{ng}$ and $0.6 \mathrm{ng}$, respectively, for all compounds.

All samples were measured in duplicate, and a difference of less than $25 \%$ was considered acceptable, as stated in the TO-15 Method [13]. The concentration determined in each exhaust phase was corrected by the dilution ambient air used in each phase. Since the dilution air was pumped from the laboratory where the driving test was conducted, and no filters were used to retain the organic compounds, the composition of the dilution air changed during the test and the concentration of hydrocarbons was different in the three dilution bags.

The sample volume was adjusted for each test to obtain a chromatographic response consistent with the range of the analytical curve. Typically, $8-200 \mathrm{~mL}$ were analyzed. As sample concentrations covered a large range, two different volumes were analyzed. Typically, the chromatographic analysis of the samples collected in one test required at least 48 hours, 
considering the blanks of the six clean sampling canisters, the analytical curve and the analysis of the three exhaust samples and the three air dilution samples.

The concentrations of the exhaust samples were calculated, for each phase in the driving cycle, using Equation 1:

$\mathrm{CC}_{\mathrm{x}}=\mathrm{EC}_{\mathrm{x}}-\left[\mathrm{DAC}_{\mathrm{x}}\left(1-1 / \mathrm{DF}_{\mathrm{x}}\right)\right]$

Equation 1

where:

$\mathrm{CC}_{\mathrm{x}}=$ Calculated concentration for phase $\mathrm{x}$

$\mathrm{EC}_{\mathrm{x}}=$ Concentration determined in the vehicular exhaust (phase $\mathrm{x}$ )

$\mathrm{DAC}_{\mathrm{x}}=$ Concentration determined in the dilution ambient air (phase $\mathrm{x}$ )

$\mathrm{DF}_{\mathrm{x}}=$ Dilution factor reported for each phase in the test report (phase $\mathrm{x}$ )

$\mathrm{x}=$ phase 1 or phase 2 or phase 3

The total mass emitted during the test was calculated using Equation 2, where the masses determined in each phase were weighted using the coefficients reported in the ABNT NBR 6601 document.

$\mathrm{E}=0.43[(\mathrm{E} 1+\mathrm{E} 2) /(\mathrm{D} 1+\mathrm{D} 2)]+0.57[(\mathrm{E} 3+\mathrm{E} 2) /(\mathrm{D} 3+\mathrm{D} 2)]$

Equation 2

where:

$\mathrm{E}=$ calculated emission (in mass/distance units)

$\mathrm{E} 1=$ emission determined for phase 1 (in mass units)

$\mathrm{D} 1=$ distance in phase 1

$\mathrm{E} 2=$ emission determined for phase 2 (in mass units)

$\mathrm{D} 2=$ distance in phase 2

$\mathrm{E} 3=$ emission determined for phase 3 (in mass units)

$\mathrm{D} 3=$ distance in phase 3

\subsection{Hydrocarbon determination $\left(\mathrm{C}_{2}-\mathrm{C}_{3}\right)$}

Emissions of $\mathrm{C}_{2}$ and $\mathrm{C}_{3} \mathrm{HC}$ of vehicles running with gasoline were determined using a SESAM series FTIR spectrometer and the relative concentrations of these gases were used to estimate the weighted MIR and OFP of the NMHC $\left(\mathrm{C}_{2}-\mathrm{C}_{3}\right)$. Tests were performed at the Instituto de Tecnologia para o Desenvolvimento (LACTEC) in the FTP75 cycle using the same L4 and L6 vehicles and a L5 vehicle similar to the one tested at Petrobras (same model and year and with similar mileage). The FTIR technique allows an online evaluation of compounds which are difficult to detect with a wide application for non-criteria compounds. The exhaust system of the vehicle was instrumented for the collection of raw emissions after the catalytic (tailpipe) at a frequency of $1 \mathrm{~Hz}$. A heated line $\left(191{ }^{\circ} \mathrm{C}\right)$ was used to avoid condensation and loss of compounds in secondary reactions, at a flow rate of $6 \mathrm{~L} \mathrm{~m}^{-1}$. The device was adjusted to optimize its operation in accordance with the methods for gasoline (E22).

\subsection{Average Specific Reactivity (MIR Average) Methodology}

The Maximum Incremental Reactivity scale (MIR) scale, created by William Carter and adopted by $\mathrm{CARB}$, has been used to estimate the maximum equivalent ozone that would be produced by the various species found in this measurement [17]. Briefly, the reactivity scale is based on calculations of relative ozone impacts, expressed as mass of additional ozone 
formed per mass VOC added to the emissions, for various compounds under various atmospheric conditions, given a chemical mechanism for the compounds and other relevant atmospheric species, models for various atmospheric conditions, and a modeling and reactivity assessment procedure. The values used in this work were calculated using the SAPRAC-07 mechanism and were discussed in detail by Carter [17].

The speciation information, determined for each test, was further analyzed by calculating the composite ozone forming potential of each specie and of the total HC mixture. Multiplying the mass (VOC) of the individual species by the MIR factor yields the maximum mass of ozone that might be produced by that mass of speciate (known as the ozone forming potential, OFP). The "average reactivity" of the sample is calculated by summing up the speciated mass, and the estimated ozone mass, and dividing the total ozone value by the total VOC mass, as shown in Equation 3.

MIR average $=\left[\sum\left(\mathrm{MIR}_{\mathrm{i}}\left(\mathrm{VOC}_{\mathrm{i}}\right)\right] /\right.$ total VOC concentration Equation 3

where:

MIR average $=$ Average reactivity or specific reactivity

$\mathrm{MIR}_{\mathrm{i}}=$ MIR coefficient for each compound

$[\mathrm{VOC}]_{\mathrm{i}}=$ concentration of each compound in $\mu \mathrm{g} \mathrm{m}^{-3}$

\section{RESULTS AND DISCUSSION}

\subsection{Gasoline tests}

The determined concentrations of the exhaust samples are shown in Table 1. As expected, for all tests, emissions are higher for phase 1 (cold start transient phase) and the lowest values were obtained for phase 2 (stabilized). Also, as expected, emissions decrease with required limits (L4 > L5 > L6). The five most abundant compounds were toluene, methylbutane (isopentane), n-pentane, 2,2,4-trimethypentane (isooctane) and benzene, in good agreement with published results for other technical studies [8]; [18]; [19]. Differences between the first and second test were expected and have been discussed in the literature. Haskew and Liberty [20], performed tests using three fuels (E6, E45.5 and E85) and the total NMHC determined in four tests, using the same vehicle, fuel and driving conditions, presented differences up to $30 \%$, from the mean value for the cold start phase. The error in the determinations for phases 1 and 3 are within the variability of Method TO-15 [13]; [14]. The error for phase 2 results is high because the difference between concentrations in the exhaust sample and the dilution air is very small and could only be decreased using purified air to dilute samples.

Emission values, in units of $\mathrm{g} \mathrm{km}^{-1}$, are shown in Table 2 for $\mathrm{HC}$ in the interval $\mathrm{C}_{4}-\mathrm{C}_{12}$. Previous results obtained by Melo et al. [5] indicated that $\mathrm{C}_{2}-\mathrm{C}_{3} \mathrm{HC}$ represent approximately $21 \%$ of the total $\mathrm{C}_{2}-\mathrm{C}_{12} \mathrm{HC}$. Considering this value, a total emission factor was estimated and is also reported in Table 2. Values obtained by Melo et al. [5], for a PROCONVE L3 vehicle, are also shown for comparison. As expected, the emission value for the PROCONVE L3 vehicle was higher than values determined in this study. 
Table 1. Total determined $\mathrm{HC}\left(\mathrm{C}_{4}-\mathrm{C}_{12}\right)$ for exhaust emissions of three flex-fuel vehicles using gasoline (E22) and the FTP 75 driving cycle.

\begin{tabular}{|c|c|c|c|c|c|c|c|c|c|c|c|c|}
\hline Phase & \multicolumn{12}{|c|}{ Total determined $\mathrm{HC}\left(\mathrm{C}_{4}-\mathrm{C}_{12}\right)$} \\
\hline \multicolumn{13}{|c|}{ PROCONVE L4 flex-fuel vehicle (gasoline E22) } \\
\hline & \multicolumn{4}{|c|}{ First determination } & \multicolumn{4}{|c|}{ Second determination } & \multicolumn{4}{|c|}{ Mean values } \\
\hline & $\mathrm{ppb}$ & ppmC & $\mu \mathrm{g} \mathrm{m}^{-3}$ & $\mathrm{~g} \mathrm{~km}^{-1}$ & $\mathrm{ppb}$ & ppmC & $\mu \mathrm{g} \mathrm{m}^{-3}$ & $\mathrm{~g} \mathrm{~km}^{-1}$ & ppmC & sd & $\mathrm{g} \mathrm{km}^{-1}$ & $\mathrm{sd}$ \\
\hline P1 & 2110.663 & 13.387 & 7521.599 & 0.0992 & 2961.681 & 18.704 & 10528.716 & 0.1390 & 16.04 & 3.76 & 0.119 & 0.028 \\
\hline $\mathbf{P 2}$ & 68.034 & 0.395 & 222.073 & 0.0046 & 130.200 & 0.990 & 555.395 & 0.0116 & 0.40 & 0.12 & 0.008 & 0.005 \\
\hline $\mathbf{P 3}$ & 546.742 & 3.066 & 1766.333 & 0.0232 & 872.424 & 4.999 & 2865.817 & 0.0377 & 4.03 & 1.37 & 0.030 & 0.010 \\
\hline \multicolumn{13}{|c|}{ PROCONVE L5 flex-fuel vehicle (gasoline E22) } \\
\hline & \multicolumn{4}{|c|}{ First determination } & \multicolumn{4}{|c|}{ Second determination } & \multicolumn{4}{|c|}{ Mean values } \\
\hline & $\mathrm{ppb}$ & ppmC & $\mu \mathrm{g} \mathrm{m}^{-3}$ & $\mathrm{~g} \mathrm{~km}^{-1}$ & $\mathrm{ppb}$ & ppmC & $\mu \mathrm{g} \mathrm{m}^{-3}$ & $\mathrm{~g} \mathrm{~km}^{-1}$ & ppmC & $\mathrm{sd}$ & $\mathrm{g} \mathrm{km}^{-1}$ & $\mathrm{sd}$ \\
\hline P1 & 1401.911 & 9.250 & 5176.186 & 0.0683 & 1810.373 & 11.591 & 6493.366 & 0.0860 & 10.4 & 1.6 & 0.077 & 0.012 \\
\hline $\mathbf{P 2}$ & 18.548 & 0.114 & 64.479 & 0.0013 & 36.929 & 0.224 & 126.268 & 0.0026 & 0.17 & 0.08 & 0.0019 & 0.0009 \\
\hline $\mathbf{P 3}$ & 129.139 & 0.829 & 472.277 & 0.0062 & 165.322 & 0.909 & 527.251 & 0.0069 & 0.87 & 0.06 & 0.0065 & 0.0004 \\
\hline \multicolumn{13}{|c|}{ PROCONVE L6 flex-fuel vehicle (gasoline E22) } \\
\hline & \multicolumn{4}{|c|}{ First determination* } & \multicolumn{4}{|c|}{ Second determination* } & \multicolumn{4}{|c|}{ Mean values } \\
\hline & $\mathrm{ppb}$ & ppmC & $\mu g \mathrm{~m}^{-3}$ & $\mathrm{~g} \mathrm{~km}^{-1}$ & $\mathrm{ppb}$ & ppmC & $\mu \mathrm{g} \mathrm{m}^{-3}$ & $\mathrm{~g} \mathrm{~km}^{-1}$ & ppmC & $\mathrm{sd}$ & $\mathrm{g} \mathrm{km}^{-1}$ & $\mathrm{sd}$ \\
\hline P1 & 576.079 & 3.480 & 1973.778 & 0.0265 & 251.746 & 1.529 & 865.411 & 0.0116 & 2.50 & 1.39 & 0.019 & 0.010 \\
\hline $\mathbf{P 2}$ & 43.519 & 0.283 & 156.167 & 0.0032 & 11.458 & 0.078 & 43.097 & 0.0010 & 0.19 & 0.14 & 0.002 & 0.001 \\
\hline P3 & nd & nd & nd & nd & 27.671 & 0.175 & 98.463 & 0.0013 & nd & nd & nd & nd \\
\hline $\begin{array}{l}\text { rst } \\
\text {. }\end{array}$ & $\begin{array}{l}=\text { standa } \\
\text { erminatio }\end{array}$ & $\begin{array}{l}\text { deviatic } \\
\text { August }\end{array}$ & $\begin{array}{l}n ; n d=\text { no } \\
2018 ; \text { seco }\end{array}$ & $\begin{array}{l}\text { eterminec } \\
\text { determin }\end{array}$ & on: April 2 & & & & & & & \\
\hline
\end{tabular}


Table 2. Experimental emission values calculated, using Equation 2, for $\mathrm{C}_{4}-\mathrm{C}_{12} \mathrm{HC}$ and estimated values for $\mathrm{C}_{2}-\mathrm{C}_{12} \mathrm{HC}$, in units of $\mathrm{g} \mathrm{km}^{-1}$. The $\mathrm{C}_{2}-\mathrm{C}_{3} \mathrm{HC}$ fraction was considered as $21 \%$ of total $\mathrm{C}_{2}-\mathrm{C}_{12} \mathrm{HC}$. Values published in the literature are also shown. The tests were run using gasoline E22. Results are the mean value of tests reported in Table 1.

\begin{tabular}{lccl}
\hline Vehicle & $\mathbf{C}_{\mathbf{4}}-\mathbf{C}_{\mathbf{1 2}} \mathbf{H C}$ & $\mathbf{C}_{\mathbf{2}}-\mathbf{C}_{\mathbf{1 2}} \mathbf{H C}$ & Observations \\
\hline PROCONVE L4 & 0.037 & 0.047 & This study \\
PROCONVE L5 & 0.017 & 0.022 & This study \\
PROCONVE L6 & 0.004 & 0.005 & This study \\
PROCONVE L3 & 0.051 & 0.065 & Melo et al. [5] \\
\hline
\end{tabular}

Graner et al. [6] also determined the NMHC emission value for a L5 flex-fuel vehicle (model $2012 / 2013$ ) as $0.018 \mathrm{~g} \mathrm{~km}^{-1}$, which is also in good agreement with the value calculated in this work for the PROCONVE L4 vehicle (model 2011).

\subsection{Ethanol tests}

Two previous studies showed high amounts of aromatic hydrocarbons in the NMHC exhaust composition (22\% to 55\%) when running with ethanol [5]; [6]. These results have not been explained since it is expected that the main products of incomplete ethanol combustion were ethane, ethene, acetaldehyde, formaldehyde and unburned ethanol [21].

Concentrations determined in this study are presented in Table 3 were the total $\mathrm{HC}\left(\mathrm{C}_{4}-\mathrm{C}_{12}\right)$ and aromatic compounds (BTEX $=$ benzene + toluene + ethylbenzene + xylenes) are reported in units of ppmC.

Table 3. Total $\mathrm{HC}\left(\mathrm{C}_{4}-\mathrm{C}_{12}\right)$ and aromatic compounds (BTEX) in units of ppmC for the emissions of the vehicles using ethanol (E100). Results are the mean value of two tests.

\begin{tabular}{lcc}
\hline Phase & Total HC $\left(\mathbf{C}_{\mathbf{4}}-\mathbf{C}_{\mathbf{~} 2}\right)$ & Aromatic compounds (BTEX) \\
\hline & PROCONVE L4 flex-fuel vehicle (E100) \\
P1 & 1.99 & 0.90 \\
P2 & 0.59 & 0.14 \\
P3 & 0.64 & 0.23 \\
Weighted value & 1.06 & 0.42 \\
& PROCONVE L5 flex-fuel vehicle (E100) \\
P1 & 0.84 & 0.71 \\
P2 & 0.50 & 0.26 \\
P3 & 0.49 & 0.26 \\
Weighted value & 0.61 & 0.41 \\
& PROCONVE L6 flex-fuel vehicle (E100) \\
P1 & 0.18 & 0.06 \\
P2 & 0.08 & 0.05 \\
P3 & 0.10 & 0.04 \\
Weighted value & 0.12 & 0.05 \\
\hline
\end{tabular}

Concentrations of aromatic compounds were $<1 \mathrm{ppmC}$ for all phases and vehicles. The weighted values were 0.05 and approximately $0.4 \mathrm{ppmC}$ for PROCONVE L6 and for PROCONVE L4-L5 vehicles, respectively. Considering the total NMHC reported for the tests, the BTEX concentration values represent $<1 \%$ for the P1 emission of the three vehicles. 
For comparison, total $\mathrm{HC}\left(\mathrm{C}_{4}-\mathrm{C}_{12}\right)$ concentrations in the dilution air and in the ambient air were in the interval $0.49-1.25 \mathrm{ppmC}$ for all tests and phases, while aromatic compounds levels were in the interval from 0.22 to $0.88 \mathrm{ppmC}$. For P2 and P3, BTEX represent a higher fraction, but the result may be due to the small differences between blank (dilution air) and exhaust samples which are of the same order of the analytical precision of the method and lead to several negative values for calculated exhaust concentrations (after correction for dilution). Since in these calculations all negative values were considered zero, the reported concentrations are an upper limit. It is worth noting that, for Method TO-15, the expected replicate precision is $25 \%$ and the performance criterion for audit accuracy is $30 \%$, according to US EPA recommendations [13]. The determined compounds may be related to the nonburned pollutants present in the ambient air and also to the lubricant and/or the filter, which were not replaced before the test and after using gasoline, the catalyst and to variations in the dilution ambient air. Further improvements in the methodology may be introduced to reduce these concentrations, such as the use of purified air to dilute the samples, the use of a more rigorous procedure to change the fuel from gasoline to ethanol, the replacement of lubricants, filters and catalyst prior the change of fuel and also a more efficient system of air conditioning in the laboratory where the test are been performed.

Since the above considerations suggest that these compounds are not due to the combustion of ethanol, the contribution of total $\mathrm{HC}\left(\mathrm{C}_{4}-\mathrm{C}_{12}\right)$ to reactivity was considered negligible.

\subsection{Average Specific MIR for the $\mathrm{C}_{4}-\mathrm{C}_{12}$ compounds}

Using Equation 3 the MIR average for each vehicle running with gasoline was calculated, considering the $\mathrm{C}_{4}-\mathrm{C}_{12} \mathrm{HC}$ fraction, as shown in Table 4 . The units of the average reactivity are in grams of ozone per gram of volatile organic compound.

Table 4. Experimental Average MIR (specific reactivity) calculated using Equation 3, emission values $\left(\mathrm{g} \mathrm{km}^{-1}\right)$ and OFP $\left(\mathrm{gO}_{3} \mathrm{~km}^{-1}\right)$, for $\mathrm{C}_{4}-\mathrm{C}_{12} \mathrm{HC}$, for phase $1(\mathrm{P} 1)$, phase $2(\mathrm{P} 2)$, phase $3(\mathrm{P} 3)$ and weighted values (W). Values do not include carbonyl compounds and ethanol contribution. The tests were performed using gasoline E22. Results are the mean value of tests reported in Table 1.

\begin{tabular}{lccc}
\hline Phase & Average MIR & Emission & OFP \\
\hline P1 & PROCONVE L4 vehicle & (gasoline E22) \\
P2 & 3.04 & 0.139 & 0.422 \\
P3 & 2.48 & 0.012 & 0.029 \\
W & 1.91 & 0.038 & 0.072 \\
& 2.68 & 0.037 & 0.099 \\
P1 & PROCONVE L5 vehicle & (gasoline E22) \\
P2 & 3.03 & 0.086 & 0.260 \\
P3 & 3.05 & 0.003 & 0.008 \\
W & 2.30 & 0.007 & 0.016 \\
& 2.76 & 0.017 & 0.051 \\
P1 & PROCONVE L6 vehicle (gasoline E22) & \\
P2 & 2.27 & 0.019 & 0.043 \\
P3 & 3.46 & 0.002 & 0.007 \\
W & $3.58^{*}$ & $0.001 *$ & $0.005^{*}$ \\
\hline
\end{tabular}

Note: * one determination 
The contribution of each compound to ozone formation depends on the concentration and the MIR factor (in $\mathrm{gO}_{3} / \mathrm{gVOC}$ ). In Table 5 the top 6-compounds considering mass abundance and MIR reactivity are listed. These compounds were the most abundant for the three vehicles.

Table 5. Top 6-compounds $\left(\mathrm{C}_{4}-\mathrm{C}_{12}\right)$ considering mass abundance and OFP of each compound (calculated as $\mathrm{MIR}_{\mathrm{i}} *\left[\mathrm{VOC}_{\mathrm{i}}\right]$ ). The top 6-MIR values determined by Carter [17] are also shown.

\begin{tabular}{ccc}
\hline Mass abundance & MIR value (Carter [17]) & OFP $_{\mathbf{i}}$ \\
\hline Toluene & $1,2,3$-trimethylbenzene & toluene \\
Isopentane & $1,2,3$-trimethylbenzene & $(\mathrm{m}+\mathrm{p})$-xylene \\
n-pentane & trans-2-pentene & isopentane \\
2,2,4-trimethylpentane & cis-2-pentene & $1,3,5$-trimethylbenzene \\
Benzene & $1,2,4$-trimethylbenzene & trans-2-pentene \\
$(\mathrm{m}+\mathrm{p})$-xylene & $(\mathrm{m}+\mathrm{p})$-xylene & $\mathrm{n}$-pentane \\
\hline
\end{tabular}

Alkanes and aromatic compounds are the most abundant for the $\mathrm{C}_{4}-\mathrm{C}_{12}$ fraction, while aromatic compounds are in general more reactive (mainly xylenes and alkylbenzenes). This information may be used in a future discussion regarding formulation of new fuels.

\subsection{Average Specific MIR for Entire NMHC}

The total MIR average could not be calculated since, as previously discussed, the chromatographic method was not appropriate to determine ethane, ethene, propane and propene. Then, the distribution of these compounds in the tests with gasoline was determined by FTIR, as shown in Table 6. The contribution of ethene (MIR =9.0) and propene (MIR = 11.6) to the MIR calculation are the most important. Values for the $\mathrm{C}_{2}-\mathrm{C}_{12}$ fraction in total NMHC were estimated using results determined by Melo et al. [5]. Following that study, the approximate mass contribution of the $\mathrm{C}_{2}$ and $\mathrm{C}_{3}$ is $21 \%$. Using these values, a weighted specific MIR for the $\mathrm{C}_{2}-\mathrm{C}_{3}$ fraction was estimated as approximately 7.30-7.71, resulting in values from 3.36 to 3.76 for MIR of entire NMHC. These values are similar to the MIR found by Melo et al. [5] in gasoline tests (3.83) and lower than the one determined by Graner et al. [6] (4.75). Values for the $C_{2}-C_{12} H C$ mixture, obtained using this value (for $C_{2}$ and $C_{3}$ ) and the experimental results for the $\mathrm{C}_{4}-\mathrm{C}_{12}$ fraction, are presented in Table 7 .

Table 6. Relative mass contribution of compounds to the $\mathrm{C}_{2}-\mathrm{C}_{3}$ fraction for the vehicles, using gasoline (E22). Percentages were estimated using FTIR results.

\begin{tabular}{rrrrrrrr}
\hline Vehicle & Ethene & Propene & Acetylene & Ethane & Propane & Propyne & $\begin{array}{r}\text { MIR } \\
\mathbf{C}_{2}-\mathbf{C}_{3}\end{array}$ \\
\hline L4 & $28 \%$ & $39 \%$ & $23 \%$ & $10 \%$ & $0 \%$ & $0 \%$ & 7.30 \\
L5 & $27 \%$ & $42 \%$ & $21 \%$ & $11 \%$ & $0 \%$ & $0 \%$ & 7.52 \\
\hline L6 & $24 \%$ & $46 \%$ & $19 \%$ & $11 \%$ & $0 \%$ & $0 \%$ & 7.71 \\
\hline
\end{tabular}


Table 7. Estimated Average MIR (specific reactivity), emission values $\left(\mathrm{g} \mathrm{km}^{-1}\right)$ and OFP $\left(\mathrm{gO}_{3}\right.$ $\mathrm{km}^{-1}$ ), for $\mathrm{C}_{2}-\mathrm{C}_{12} \mathrm{HC}$. Values do not include carbonyl compounds and ethanol contribution. The tests were performed using gasoline E22.

\begin{tabular}{llcc}
\hline & Average MIR & Emission & OFP \\
\hline W & PROCONVE L4 vehicle & (gasoline E22) & \\
& 3.65 & 0.047 & 0.17 \\
W & PROCONVE L5 vehicle & (gasoline E22) & \\
& 3.76 & 0.022 & 0.08 \\
W & PROCONVE L6 vehicle & (gasoline E22) & \\
\hline
\end{tabular}

\subsection{Sources of Uncertainty}

The accuracy, reliability and representativeness of emission factors and reactivity calculations depend on the quality of the emission measurement method which involves the driving test and the analytical method to quantify the hydrocarbons. The calculation of uncertainties in the determination of vehicular emissions has been discussed by Melo [22]. Many parameters related to the driving test and to the analytical procedure contribute to the uncertainties.

In 2009, Joumard et al. [23] published a technical paper with the findings of 10 European laboratories which investigated the influence of 20 parameters on the measurements of lightvehicles emission factors on chassis dynamometer, considering driving patterns, vehicle related parameters, vehicle sampling and laboratory-related parameters. The study considered data from 183 vehicles and more than 3500 tests. Parameters as gearshift strategy, vehicle mileage, ambient temperature, humidity, dilution ratio and driving cycle were highly influential. The effect of the sampling and analytical methods was not investigated but is certainly very important.

Speciation is currently performed by gas chromatography using either a flame ionization (FID) or a mass spectrometry (MS) detector. When using a FID detector, the calibration standard for all target hydrocarbons is, in general, propane, as described by CARB 1001 and 1002 Methods [15]. When using an MS detector, a VOC mixture containing all the target compounds and individual calibration curves should be used as described in US EPA Method TO-15 for ambient samples [13]. Sampling procedures also determine the integrity of samples. When using Tedlar bags, they must be shielded from direct sunlight and cold-start samples must be analyzed within 8 hours while all other samples could be analyzed within 24 hours, although analysis within 8 hours is recommended [15]. When using canisters, the sample is protected from sunlight and the sample integrity is maximized. Experiments performed in our laboratory showed that samples could be analyzed within a week while 4872 hours is recommended. However, in all these methods experimental errors are expected to be high (20-30\%) and, then, results may only be rigorously compared when the same method is used. Other methods, such us Fourier transform infrared spectroscopy (FTIR) are currently used. As described by Ropkins et al. [24], total hydrocarbons (THC) measurements are not directly equivalent to the values measured by legislated FID instruments because the two analyzer systems measure different properties of hydrocarbons. The FTIR tended to underestimate THCs by comparison to FID [24]; [25]. The FTIR uses infrared absorbance to measure the concentrations of individual hydrocarbons (typically up to 39 compounds are determined) and, then, these values are summed to estimate total THC emissions. The FID 
measures carbon combustion and reports this as a methane equivalent THC using a unique standard [24]. Correction factors should be applicate to obtain equivalent results.

\section{CONCLUSIONS}

This study describes a method to determine the hydrocarbons, in the interval $\mathrm{C}_{4}-\mathrm{C}_{12}$, emitted by flex-fuel vehicles using gasoline (E22) and ethanol (E100), based on the ABNT NBR 6601 Brazilian Standards and Method TO-15 (US-EPA) to determine volatile organic compounds. Using gasoline, E22, experimental emission values for phase 1 were $0.119,0.105$ and $0.026 \mathrm{~g}$ HC $\left(\mathrm{C}_{4}-\mathrm{C}_{12}\right) \mathrm{km}^{-1}$ for PROCONVE L4, L5 and L6 tested vehicles, respectively. Using hydrous ethanol and the PROCONVE L6 vehicle, the aromatic compounds were $<0.4$ ppmC in all phases. For the PROCONVE L5 and L4 vehicles the aromatic compounds represented $0.5-0.6$ ppmC. These values represent approximately $2 \%$ for the L6 vehicle e $1 \%$ for the L5 and L4 vehicles and are probably not related to the ethanol combustion process, so in this case the contribution of total $\mathrm{HC}\left(\mathrm{C}_{4}-\mathrm{C}_{12}\right)$ to reactivity was considered negligible. For $\mathrm{C}_{4}-\mathrm{C}_{12}$ hydrocarbons determined for tests with gasoline, weighted MIR and OFP values were approximately in the intervals 2.20-2.76 and 0.013-0.099, respectively. Considering the $\mathrm{C}_{2}$ $\mathrm{C}_{12} \mathrm{HC}$ fraction estimated using FTIR results of tests with gasoline, the values of MIR and OFP were approximately 3.36-3.76 and 0.02-0.17, respectively. These values are similar to the MIR found by Melo et al. [5] in gasoline tests and lower than the one determined by Graner et al. [6]. Since it was noticed the importance of $\mathrm{C}_{2}-\mathrm{C}_{3}$ fraction to the total specific reativity a chromatographic method optimized for low molecular weight-compounds will be implemented in future studies. Literature indicates that the main $\mathrm{HC}$ products of incomplete ethanol combustion are acetylene and ethene, which have very different MIR each other $(0.95$ and 9.0, respectively), so these new studies should allow to calculate MIR of exhaust gases from the combustion of hydrous ethanol in an accuracy way.

\section{REFERENCES}

[1] CONAMA. Ministério do Meio Ambiente. Resolução 491/2018. Available from: http://www2.mma.gov.br/port/conama/legiabre.cfm?codlegi=740. Accessed April 28, 2019.

[2] Atkinson, R. Atmospheric Chemistry of VOCs and $\mathrm{NO}_{\mathrm{x}}$. Atmospheric Environment, 34, 2063-2101, 2000.

[3] Finlayson-Pitts, B. J.; Pitts, J. N. Chemistry of the Upper and Lower Atmosphere. Theory, Experiments and Applications. Third Edition. Academic Press: San Diego. 2000.

[4] Seinfeld, J. H.; Pandis, S. N. Atmospheric Chemistry and Physics: From air pollution to climate change. $3^{\text {rd }}$ Edition, Wiley: Australia. 2016.

[5] Melo, T. C. C.; Vicentini, P. C.; Loureiro, L. N.; Moreira, E.; Almeida, J. C. S. Ozone formation-Reactivity emission factors of light duty vehicles using gasoline and ethanol. SAE International. 2014.

[6] Graner, L.; Garcia, I. S.; Joseph Jr., H. Estudo comparativo dos hidrocarbonetos emitidos pelo gás de escapamento de um veículo flex quanto abastecido com E22 e com E100. SIMEA, SP. 2013.

[7] Barlow, T. J.; Latham, S.; McCrae, I. S.; Boulter, P. G. A reference book of driving cycles for use in the measurement of road vehicles emissions. Department for Transport, Cleaner Fuels ad Vehicles. 2009. 
[8] Wang, J.; Jin, L.; Gao, J.; Shi, J.; Zhao, Y.; Liu, S.; Jin, T., Bai, Z.; Wu, C. Investigation of speciated VOC in gasoline vehicular exhaust under ECE and EUDC test cycles. Science of the Total Environment, 445-446, 110-116. 2013.

[9] ABNT. Norma Brasileira ABNT NBR 6601. Veículos rodoviários automotores leves. Determinação de hidrocarbonetos, monóxido de carbono, óxidos de nitrogênio, dióxido de carbono e material particulado no gás de escapamento. 2012.

[10] US EPA. Vehicle and fuel emission testing. Dynamometer drive schedules. Available from: https://www.epa.gov/vehicle-and-fuel-emissions-testing/dynamometer-drive-schedules. Accessed April 28, 2019.

[11] US EPA. EPA Federal Standard Test Procedure, FTP. Available from: https://www.epa.gov/emission-standards-reference-guide/epa-federal-test-procedure-ftp.

Accessed April 28, 2019.

[12] EU. EU light duty: New European Driving cycle. Transport Policy.net. Available from: https://www.transportpolicy.net/standard/eu-light-duty-new-european-driving-cycle/.

Accessed April 28, 2019.

[13] US EPA. Compendium Method TO-15. Determination Of Volatile Organic Compounds (VOCs) In Air Collected In Specially-Prepared Canisters And Analyzed By Gas Chromatography/ Mass Spectrometry (GC/MS). 1999

[14] Silva, CM; Souza, EC; da Silva, LL; Oliveira, RL; Correa, SM; Arbilla, G. Avaliação da eficiência do Método TO-15 para determinação de compostos orgânicos voláteis em condições típicas de ambiente urbano. Química Nova, 39 (10), 1245-1253. 2016.

[15] CARB. California non-methane organic gas test procedures. 2002. Available from: https://www.arb.ca.gov/msprog/levprog/cleandoc/clean_nmogtps_final.pdf._Accessed April $28,2019$.

[16] Hoekman, S. K. Improved gas chromatography procedure for speciated hydrocarbons measurements of vehicle emissions. Journal of Chromatography, 639, 239-253, 1993.

[17] Carter, W. P. L. Updated Maximum Incremental Reactivity Scale For Regulatory Applications, 2010. College of Engineering Center for Environmental Research and Technology, University of California, Riverside. Available from: https://www.researchgate.net/publication/284060890_Updated_maximum_incremental_reacti vity_scale_and_hydrocarbon_bin_reactivities_for_regulatory_applications. Accessed April 28, 2019.

[18] Schuetzle, D.; Siegl, W. O.; Jensen, T. E.; Dearth, M. A.; Kaiser. E. W.; Gorse, R.; Kreucher, W.; Kulik, E. The relationship between gasoline composition and vehicle hydrocarbon emissions: A review of current studies and future research needs. Environmental Health Pesrspectives, 102, 3-12. 1994.

[19] Nakashima, Y.; Kamei, N.; Kobayashi, S.; Kajaii, Y. Total OH reactivity and VOC analysis for gasoline vehicular exhaust with a chassis dynamometer. Atmospheric Environment, 44, 468-475. 2010.

[20] Haskew, H. M.; Liberty, T. F. Exhaust and evaporative emissions testing of flexible-fuel vehicles. CRC Report Number E-80 2011. Available from: https://crcao.org/reports/recentstudies2011/E-80/E-80\%20Final\%20Report+Appendices.pdf. Accessed April 28, 2019.

[21] Saxena, P.; Williams, F. A. Numerical and experimental studies of etanol flames. Procceedings of the Combustion Institute, 31, 1149-1156, 2007.

[22] Melo, T. C. C. Incerteza de medição em ensaios de emissões veiculares-Proposta de metodologia de cálculo. Available from: http://www.inmetro.gov.br/metcientifica/palestras/TadeuMelo2.pdf. Accessed April 28, 2019. 
[23] Joumard, R.; Laurikko, J.; Le han, T.; Geivanidis, S.; Samaras, Z.; Merétei, T.; Devaux, P.; André, J. M.; Cornelis, E.; Lacour, S.; Prati, M. V.; Vermeleulen, R.; Zallinger, M. Accuracy of exhaust emission factor measurements on chassis dynamometer. Journal of the Air \& Waste Management Association, 59, 695-703.2009.

[24] Ropkins, L. H.; Andrews, G. E.; Daham, B.; Bell, M.; Tate, J.; Hawley, G. Evaluation of FTIR emission measurement system for legislated emissions using a SI car. SAE technical paper 2006-01-3368. 2006.

[25] Daham B.; Andrews G.E.; Li H., Bellesteros R.; Bell M.; Tate J.; Ropkins K. Application of a Portable FTIR for Measuring on road Emissions. SAE technical paper 2005-01-0676. 2005. 